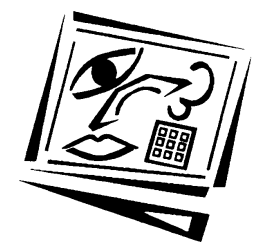

\title{
Are learning style preferences of health science students predictive of their attitudes towards e-learning?
}

\author{
Ted Brown \\ Monash University \\ Maryam Zoghi \\ The University of Melbourne \\ Brett Williams, Shapour Jaberzadeh, Louis Roller, Claire Palermo, Lisa \\ McKenna, Caroline Wright, Marilyn Baird, Michal Schneider-Kolsky, Lesley \\ Hewitt \\ Monash University \\ Jenny Sim \\ RMIT University \\ Tangerine-Ann Holt \\ Monash University
}

\begin{abstract}
The objective for this study was to determine whether learning style preferences of health science students could predict their attitudes to e-learning. A survey comprising the Index of Learning Styles (ILS) and the Online Learning Environment Survey (OLES) was distributed to 2885 students enrolled in 10 different health science programs at an Australian university. A total of 822 useable surveys were returned generating a response rate of $29.3 \%$. Using SPSS, a linear regression analysis was completed. On the ILS Active-Reflective dimension, $44 \%$ of health science students reported a preference as being active learners, $60 \%$ as sensing learners, and $64 \%$ as sequential learners. Students' attitudes toward e-learning using the OLES showed that their preferred scores for all 9 subscales were higher than their actual scores. The linear regression analysis results indicated that ILS learning styles accounted for a small percentage of the OLES actual and preferred subscales' variance. For the OLES actual subscales, the ILS Active-Reflective and Sensing-Intuitive learning style dimensions were the most frequent predictors of health science students' attitudes towards elearning. For the OLES preferred subscales, ILS Active-Reflective and Sequential-Global learning style dimensions accounted for the most frequent source of variance. It appears that the learning styles of health science students (as measured by the ILS) can be used only to a limited extent as a predictor of students' attitudes towards elearning. Nevertheless, educators should still consider student learning styles in the context of using technology for instructional purposes.
\end{abstract}

\section{Introduction}

Learning style refers to the way individuals prefer to process new information and strategies they adopt for effective learning (Huston \& Cohen, 1995). Research indicates that people differ in their approach to learning and that no one strategy or approach will result in optimal learning circumstances for all individuals. E-learning utilises technologies, such as web based education methods, podcasting, social networking software, Internet video conferencing, or computer assisted instruction, and are 
gaining popularity in the tertiary education sector (Chang, 1984; Fleming et al., 2003). E-learning permits the adaptation of education content to suit individual student learning styles, incorporating more visual media, graphics, digitised materials, interactive videos, or web based interactions as appropriate. Use of technology and elearning strategies is increasing in the health science education field (Lynch et al., 1998; Ogilvie et al., 1999; Cook, 2005). While e-learning theoretically allows for the adjustment of educational content to meet student learning needs, the majority of research in this area has been confined to standard instructional formats (such as lecture, tutorial, written text, or problem based learning) and digitised material. The relationship between learning styles and attitudes to e-learning has received moderate attention in the empirical literature to date (Startsman \& Robinson, 1972; Brudenell \& Carpenter, 1990; Effken \& Doyle, 2001). According to Grasha and Yangarber-Hicks (2000, p. 3), "Students' performance when faced with technology is very much tied to their particular learning style preferences". Therefore, the purpose of this study is to determine whether learning style preferences of health science students are predictive of their attitudes to e-learning.

\section{Literature review}

\section{Learning styles}

Learning is described as the process whereby knowledge is created through the transformation of experience. Individuals use learning to adapt to and manage everyday situations, giving rise to different styles of learning. The concept of learning styles has received considerable attention in the empirical literature and many theories have been proposed in order to better understand the dynamic process of learning (Arthurs, 2007; Coffield, Moseley, Hall \& Ecclestone, 2004). A variety of learning style theories and frameworks have been developed along with accompanying instruments that operationalise their learning style constructs (Dunn \& Griggs, 2003; Loo, 2004). Hickcox (1995) categorises learning style instruments within three groups: 1) instructional and environmental learning preferences; 2) information processing learning preferences; and 3) personality related learning preferences.

Evaluating students' learning styles provides knowledge about their particular preferences. This awareness can be used to develop, design, format, and deliver educational programs and resources that will motivate and stimulate students' acquisition, integration, and application of information and professional knowledge in an attempt to individualise instruction. "Understanding styles can improve the planning, producing, and implementing of educational experiences, so they are more appropriately compatible with students' desires, in order to enhance their learning, retention and retrieval" (Federico, 2000, p. 367).

The most common learning theory in allied health research is information processing, which considers personality theories and suggests four sequential stages during the learning process. The information processing theories are based on Lewin's Cycle of Adult Learning (Kolb, 1984). Lewin's cycle describes four stages that follow on from each other during the learning process. The first stage is concrete experience, which is followed by personal reflection on the experience. This is then combined with previous knowledge (abstract conceptualisation), and finally new ways of adjusting to experiences are explored (active experimentation) (Kolb, 1984). Kolb's Experiential Learning Cycle is one system based on Lewin's work and is the most commonly applied 
theory for health professionals (Titiloye \& Scott, 2001). Kolb supports the concept of influences on learning style from personality traits.

In Kolb's Experiential Learning Cycle, ideally an individual would cycle through all four stages (Kolb, 1984). In reality, some stages may be skipped, or one stage may become the primary focus. As described by Kolb, preferences for the concrete experience stage of learning result in learning from specific experiences or from relating to people. When the reflective observation stage is preferred, careful observation and searching for meaning is likely to be evident (Kolb, 1984). A preference for the abstract conceptualisation stage will produce logical analysis and systematic planning. The final stage of the cycle involves taking risks and pursuing activities or tasks, behaviours that are observed in an individual with a preference for active experimentation. Kolb takes the Lewin's original cycle a step further, proposing a specific learning style preference based on an individual's utilisation of the four learning phases (Kolb, 1984). The resulting learning styles are 'accommodator', 'diverger', 'converger' and 'assimilator'.

Another notable learning style model was developed by Felder and Spurlin (2005) who proposed four learning style dimensions: active/reflective, sensing/intuitive, visual/verbal, and sequential/global. According to Felder and Spurlin's learning style model, 'active learners' tend to retain and understand information best by doing something active with it, discussing or applying it, or explaining it to others while 'reflective learners' prefer to think about it quietly first. Active learners like group work more than reflective learners, who prefer working alone (Felder \& Silverman, 1988). Sitting through lectures without getting to do anything physical other than take notes is hard for both learning types, but particularly hard for active learners.

'Sensing learners' tend to like learning facts, whilst 'intuitive learners' often prefer discovering possibilities and relationships. Sensors often like solving problems by well-established methods and dislike complications and surprises; intuitors like innovation and dislike repetition. Intuitors are less likely than sensors to resent being tested on material that has not been explicitly covered in class (Felder, 1993). Sensors tend to be patient with details, good at memorising facts, and doing hands on (laboratory) work; intuitors may be better at grasping new concepts and are often more comfortable than sensors with abstractions and mathematical formulations. Intuitors tend to work faster and be more innovative than sensors, while sensors tend to be more practical and careful than intuitor counterparts. Intuitors do not like educational activities that involve a lot of memorisation and routine calculations, while sensors do not like courses that have no apparent connection to the real world (Felder \& Silverman, 1988).

'Visual learners' remember best what they see, for example pictures, diagrams, flow charts, time lines, films, and demonstrations (Felder \& Silverman, 1988), while 'verbal learners' get more out of words (written and spoken explanations) (Felder, 1993). Everyone learns more when information is presented both visually and verbally. Traditionally in most university lectures, little visual information is presented other than PowerPoint slides or plastic overhead projector sheets. Students mainly listen to lectures and read material written on boards and in textbooks and handouts. Unfortunately, most people are visual learners, which means that most students do not get nearly as much as they would if more visual presentation aids were used in classroom contexts (Sims \& Sims, 2006). Adaptable learners are capable of processing information presented either visually or verbally. 
'Sequential learners' tend to gain understanding in linear steps, with each step following logically from the previous one. 'Global learners' tend to learn in large jumps, absorbing material almost randomly without seeing connections, and then suddenly "getting it." Sequential learners prefer to follow logical stepwise paths in finding solutions; global learners may be able to solve complex problems quickly or put things together in novel ways once they have grasped the big picture, but they may have difficulty explaining how they did it.

\section{Use of e-learning in teaching contexts and its relation to learning styles}

E-learning in the most general sense is defined as the use of technologies in learning opportunities (Alonso, Lopez, Manrique \& Vines, 2005). In other words, e-learning involves the acquisition of knowledge and skill using electronic technologies such as computer and Internet based courseware and local and wide area networks. The learning opportunities are delivered primarily via the Internet, intranets, audio and videotape, satellite broadcast, interactive TV, and CD. Three stages of e-learning have been proposed (Mayer, 2003). The first stage, referred to as the informative stage, involves the provision of information (administrative), program specification, module handbooks, timetables, reading lists, exam questions and links to external resources. The second stage, known as the integrative stage, covers more dynamic interaction and communication replacing some face to face activity, including manipulation of online datasets, group discussion, video lectures, e-tutoring, online exercises, formative and summative assessment. The third stage, called the transformatory stage, provides an online learning community, using resources and technologies in innovative and collaborative ways, such as multimedia simulations, online seminars with invited experts (The University of Northampton, 2008).

If e-learning can permit the adaptation of education content to synchronise with individual learning styles, are attitudes to e-learning influenced by students' learning style preferences? Studies have demonstrated that a negative attitude towards computers and technology has been correlated with resistance to computerisation (Van Dover \& Boblin, 1991; Lynch et al., 1998) while other studies have indicated that attitudes towards e-learning have not had a significant impact on performances by inexperienced users of e-learning (Lynch et al., 2001). Though there have been some studies on the relationship between learning styles and the use of e-learning, evidence remains contradictory. Some findings suggest there is a strong relationship between student learning styles and attitudes to e-learning (Graff, 2003; Hong \& Kinshuk, 2004; Shih \& Gamon, 2002), whilst others suggest that no such relationship exists (Shaw \& Marlow, 1999). Further investigation is needed to clarify this issue. The relationship between learning style preferences and attitudes towards e-learning has received only cursory attention in medical (Engleberg et al., 2001; Lynch et al., 2001; Liberman et al., 2002) and nursing (Kirchhoff \& Holzemer, 1979; Brudenell \& Carpenter, 1990; Summers et al., 1993; Yoder, 1994; Effken \& Doyle, 2001) literature, while no studies to date have been reported involving other allied health disciplines.

The use of e-learning is seen as a new way of teaching and instruction that aims to educate graduates who are innovative, flexible, creative and effective problem solvers. It is also viewed as a cost effective, and quality enhancing in the health care industry, particularly in clinical informatics. Romanov and Nevgi (2007) assessed the association between the use of multimedia materials, such as video clips, and collaborative communication tools with learning outcome among 121 third-year medical students. They found no significant associations between video viewing and the time used in e- 
learning, though female students were significantly more active video viewers. Romanov and Nevgi also reported that video viewing was associated with a better course grade, concluding that students who viewed video clips were more active in using collaborative e-learning tools and achieved higher course grades.

Steele et al (2002) explored the relationship between learning style preferences, attitudes towards computers, and student evaluation of a computer assisted instructional (CAI) program amongst a group of 151 American medical students completing a surgical clerkship. The results indicated that there was no relationship between learning style preferences, computer attitudes and evaluation of the CAI program. Steele et al. (2002) concluded that "learning preferences and pre-existing attitudes towards computer technology in education do not bias acceptance or rejection of a particular CAI program" (p. 231).

Using Kolb's Learning Style Inventory with a group of undergraduate 40 registered nurses, Brudenell and Carpenter (1990) found that participants who were assimilators exhibited the most negative attitude to CAI, compared with accommodators, convergers, and divergers. On the other hand, $\mathrm{Lu}, \mathrm{Yu}$ and Liu (2003) examined a variety of factors related to students' learning performance in a web based management information systems graduate course, finding that other than ethnicity, no other factors (such as gender, age, job status, previous computer experience, and learning style preference) had an impact on students' e-learning. Another study, by Liegle and Janicki (2006), explored the effect of learning styles on the Internet navigation needs of web based learning, finding that student learners classified as 'explorers' tended to have a higher number of visits to linked web pages whereas students classified as 'observers' tended to be more passive. 'Explorers' created their own path of learning (learning control) while 'observers' followed the suggested path by clicking on the "next" button (system control).

While both educational theory and common sense argue that active learning strategies should lead to improved learning outcomes (e.g., information and skills uptake and retention) over traditional passive didactic lectures, data in the health sciences that provides an overview of teaching and learning strategies within specific learning environments are scarce. Hence, the aim of this study was to determine the relationship between learning style preferences and attitudes to e-learning in a group of health science students.

\section{Method}

Design and participants

A non-experimental prospective cohort survey study design was used. All students enrolled in occupational therapy, physiotherapy, nursing, midwifery, dietetics and nutrition, pharmacy, social work, radiation therapy, radiography, and paramedic studies at Monash University in 2006-2007 were potential respondents $(n=2885)$. The number of potential participants in each program was pharmacy 900, physiotherapy 215 , occupational therapy 134 , nursing 375, paramedics 170 , radiography 240 , social worker 606, dietetics and nutrition 162, and midwifery 83. Group sizes varied between the health professional groups since the numbers of students enrolled in each program were different. For example, occupational therapy enrolled approximately 60 students per year while pharmacy enrolled about 250 students per year. The programs also varied in regard to the type of degree conferred (three or four year undergraduate degree) and the educational prerequisites for admission. 
A power analysis suggested that a minimum of 500 participants was required for the proposed data analyses (Stein \& Cutler, 2000), indicating a response rate target of at least $20 \%$. Inclusion criteria for participants were enrolment at Monash University in a health science professional program on either a full or part time basis during 20062007, and consenting to take part in the study.

\section{Instrumentation}

A self report questionnaire was used to obtain demographic information about each participant (e.g., the health science program enrolment, year level, gender, age). The Index of Learning Styles (ILS) developed by Felder and Silverman (1988) was used to obtain data about the health science students' learning style preferences. The ILS is a 44 item scale instrument designed to assess preferences on four learning style dimensions (active/ reflective, sensing/ intuitive, visual/ verbal, and sequential/ global), based on a learning style model developed by Felder and Spurlin (2005). The ILS is a valid and reliable instrument (Litzinger, Lee, Wise \& Felder, 2007). In a recent study, Zywno (2003) collected ILS responses for several hundred Canadian engineering students to assess the ILS's test-retest reliability, internal consistency reliability, and construct validity for its four learning style subscales. She concluded that the ILS exhibited moderate to good levels of reliability and validity (Zywno, 2003). Test-retest reliability correlation coefficients ranged from .51 to .68 and internal consistency, Cronbach alpha, ranged from 053 to .70 (Zywno, 2003). Evidence of the ILS's convergent validity, construct validity based on factor analysis and discriminant validity were also reported by Zywno (2003).

Each ILS learning style dimension has 11 forced choice items, with each option (answer a or b) corresponding to one or the other learning category dimensions (e.g., active or reflective) (Litzinger, Lee, Wise \& Felder, 2007). For scoring purposes, 'a' responses are counted, so that a score on a learning dimension is an integer ranging from 0 to 11. Using the Active-Reflective learning style dimension as an example, 0 or 1 'a' responses would represent a strong preference for reflective learning, 2 or 3 a moderate preference for reflective, 4 or 5 a mild preference for reflective, 6 or 7 a mild preference for active learning, 8 or 9 a moderate preference for active, and 10 or 11 a strong preference for active. This scoring categorisation method was used in all of the statistical analyses reported in the paper.

The Online Learning Environment Survey (OLES) (Trinidad, Aldridge \& Fraser, 2005) was used to assess the health science students' attitudes toward e-learning. The OLES is a dual format instrument where students are asked to rate the actual learning environment experienced in a unit/ course/ subject/ module, compared with their preferred learning environment, using a 5-point rating scale (almost never, seldom, sometimes, often, almost always) for 'actual' and 'preferred' items. The purpose of the OLES is to provide educators using e-learning with a mechanism to reflect on the learning environment provided based on the results gained from student feedback (Trinidad, Aldridge \& Fraser, 2005). The OLES incorporates scales from five existing instruments: (1) the What Is Happening In this Class? (WIHIC) (Fraser et al., 1996) questionnaire, (2) the Constructivist Learning Environment Survey (CLES) (Taylor et al., 1997), (3) the Distance Education Learning Environments Survey (DELES) (Jegede et al., 2002; Walker \& Fraser, 2005), (4) the Technology-Rich Outcomes-Focused Learning Environment Instrument (TROFLEI) (Aldridge et al., 2003; Aldridge et al., 2004), and (5) the Test of Science-Related Attitudes (TSRA) (Fraser, 1981, 1998a, 1998b). Each of these scales has been used in past empirical studies and have been shown to be reliable and valid (Clayton, 2007; Trinidad et al., 2004). 
The OLES is made up of nine subscales comprising 54 items: (1) computer usage (CU), (2) teacher support (TS), (3) student interaction and collaboration (SIC), (4) personal relevance (PR), (5) authentic learning (AL), (6) student autonomy (SA), (7) equity (EQ), (8) enjoyment (EN), and (9) asynchronicity (AS) (Trinidad, Aldridge \& Fraser, 2005). Examples of items from each subscale are reported in Table 1. Estimation of reliability for OLES was found to be satisfactory for both the actual and preferred forms of OLES. Internal consistency (Cronbach alpha reliability) was reported by Trinidad, Aldridge and Fraser (2004) as ranging from 0.86 to 0.96 for the actual version and from 0.89 to 0.96 for the preferred version.

Table 1: Examples of items from the nine OLES subscales

\begin{tabular}{|c|c|c|c|c|}
\hline Scale & \begin{tabular}{|l|} 
No. of \\
items
\end{tabular} & Description & Sample item & $\begin{array}{c}\text { Original } \\
\text { questionnaire }\end{array}$ \\
\hline $\begin{array}{l}\text { Computer } \\
\text { usage (CU) }\end{array}$ & 6 & $\begin{array}{l}\text { The extent to which students use } \\
\text { their computers as a tool to } \\
\text { communicate with others and to } \\
\text { access information. }\end{array}$ & $\begin{array}{l}\text { I use the computer to } \\
\text { obtain information from } \\
\text { the Internet. }\end{array}$ & TROFLEI \\
\hline $\begin{array}{l}\text { Teacher } \\
\text { support (TS) }\end{array}$ & 8 & $\begin{array}{l}\text { The extent to which the teacher } \\
\text { helps, befriends, trusts and is } \\
\text { interested in students. }\end{array}$ & $\begin{array}{l}\text { The teacher gives me } \\
\text { valuable feedback on } \\
\text { my assignments. }\end{array}$ & WIHIC \\
\hline \begin{tabular}{|l|} 
Student inter- \\
action and \\
collaboration \\
(SIC)
\end{tabular} & 6 & $\begin{array}{l}\text { The extent to which students have } \\
\text { opportunities to interact with one } \\
\text { another, exchange information } \\
\text { and engage in collaboration. }\end{array}$ & $\begin{array}{l}\text { I share information with } \\
\text { other students. }\end{array}$ & DELES \\
\hline $\begin{array}{l}\text { Personal } \\
\text { relevance } \\
\text { (PR) }\end{array}$ & 5 & $\begin{array}{l}\text { The extent to which there is a } \\
\text { connection between students' out } \\
\text { of -school experiences. }\end{array}$ & $\begin{array}{l}\text { I can relate what I learn } \\
\text { to my life outside of this } \\
\text { class. }\end{array}$ & CLES \\
\hline \begin{tabular}{|l|} 
Authentic \\
learning $(\mathrm{AL})$
\end{tabular} & 5 & $\begin{array}{l}\text { The extent to which students have } \\
\text { the opportunity to solve real- } \\
\text { world problems that are authentic. }\end{array}$ & $\begin{array}{l}\text { I work on assignments } \\
\text { that deal with real } \\
\text { world information. }\end{array}$ & DELES \\
\hline $\begin{array}{l}\text { Student } \\
\text { autonomy } \\
\text { (SA) }\end{array}$ & 5 & $\begin{array}{l}\text { The extent to which students have } \\
\text { opportunities to initiate ideas and } \\
\text { make their own learning } \\
\text { decisions, and the locus of control } \\
\text { is student oriented. }\end{array}$ & $\begin{array}{l}\text { I make decisions about } \\
\text { my learning. }\end{array}$ & DELES \\
\hline Equity (EQ) & 7 & $\begin{array}{l}\text { The extent to which students are } \\
\text { treated equally by the teacher. }\end{array}$ & $\begin{array}{l}\text { I am treated the same as } \\
\text { other students in this } \\
\text { class. }\end{array}$ & WIHIC \\
\hline $\begin{array}{l}\text { Enjoyment } \\
(\mathrm{EN})\end{array}$ & 6 & $\begin{array}{l}\text { The extent to which students are } \\
\text { satisfied with their e-learning } \\
\text { environment. }\end{array}$ & $\begin{array}{l}\text { I would enjoy my } \\
\text { education if more of my } \\
\text { classes were online }\end{array}$ & TSRA \\
\hline $\begin{array}{l}\text { Asynchron- } \\
\text { icity (AS) }\end{array}$ & 6 & $\begin{array}{l}\text { The extent to which the } \\
\text { asynchronous nature of the } \\
\text { discussion forum promotes } \\
\text { reflective thinking and the posting } \\
\text { of messages at times convenient to } \\
\text { the students. }\end{array}$ & $\begin{array}{l}\text { I read the posted } \\
\text { messages at times that } \\
\text { are convenient to me. }\end{array}$ & WIHIC \\
\hline
\end{tabular}

Note: What Is Happening In this Class? (WIHIC); Constructivist Learning Environment Survey

(CLES); Distance Education Learning Environments Survey (DELES); Technology Rich Outcomes

Focused Learning Environment Instrument (TROFLEI); and Test of Science Related Attitudes (TSRA)

Data analysis

The Statistical Package for Social Sciences (SPSS) Version 15 was used for data entry, storage, retrieval, and the calculation of descriptive statistics. Mean scale scores and standard deviations were calculated for the OLES's nine actual and preferred subscales. 
A linear regression analysis was completed to determine whether any of the ILS learning style variables were significant predictors of the OLES actual and preferred subscales (that measured health science students' attitudes towards e-learning). The ILS subscale scores were correlated with the OLES subscale scores. Any of the ILS scales that correlated significantly with the OLES actual and preferred subscales were used as independent variables in the linear regression analysis. The OLES subscales were used as the dependent/ criterion variable in the linear regression analyses.

\section{Procedures}

Approval from the Monash University Committee on Ethics in Research on Humans was obtained before commencement of the project. Permission was gained from the head of department or program chairperson of each academic program to approach students about completing the survey. Participants were given a brief overview of the project, along with the distribution of the self report questionnaire during a scheduled class and were asked to participate on a voluntary basis. Questionnaires were distributed and collected by a research assistant.

\section{Results}

\section{Participant results}

A total of 835 questionnaires were returned. Thirteen of the returned questionnaires, which had over $75 \%$ of the questions not answered, were excluded from the analysis. Analyses were applied on 822 completed questionnaires. Nearly $30 \%$ of the returned questionnaires were completed by pharmacy students. The final sample contained more females $(n=671)$ than males $(n=151)$ and just over $40 \%$ were between $21-24$ years old (see Table 2). Half the students $(50 \%)$ entered their respective health science tertiary level program directly from high school, while $45.6 \%$ of the students had previous tertiary education before entering the health science program.

Table 2: Participant data

\begin{tabular}{|c|c|c|c|}
\hline & & No. of students & Percentage \\
\hline \multirow{12}{*}{$\begin{array}{l}\text { Health science } \\
\text { program }\end{array}$} & Occupational Therapy & 19 & 2.3 \\
\hline & Physiotherapy & 50 & 6.1 \\
\hline & Paramedics & 62 & 7.5 \\
\hline & Social Work & 116 & 14.1 \\
\hline & Nutrition \& Dietetics & 129 & 15.7 \\
\hline & Pharmacy & 240 & 29.2 \\
\hline & Radiation Therapy & 36 & 4.4 \\
\hline & Radiography & 35 & 4.3 \\
\hline & Nursing & 82 & 10.0 \\
\hline & Midwifery & 41 & 5.0 \\
\hline & Bachelor of Nursing/Bachelor of Emergency & 12 & 1.4 \\
\hline & Total & 822 & 100.0 \\
\hline \multirow{9}{*}{$\begin{array}{l}\text { Age of } \\
\text { participants }\end{array}$} & 15-19 years & 291 & 35.4 \\
\hline & $20-24$ years & 341 & 41.5 \\
\hline & $25-29$ years & 67 & 8.2 \\
\hline & 30-34 years & 40 & 4.9 \\
\hline & $35-39$ years & 34 & 4.1 \\
\hline & 40-44 years & 24 & 2.9 \\
\hline & $44-49$ years & 13 & 1.6 \\
\hline & 50 years or older & 12 & 1.5 \\
\hline & Total & 822 & 100.0 \\
\hline
\end{tabular}




\section{Learning style preferences}

The results of health science student learning style preferences based on the ILS are presented in Table 3. On the Active-Reflective dimension, $44.4 \%$ of health science students exhibited a preference as active learners and $23.4 \%$ as reflective learners. On the Sensing-Intuitive dimension, $60 \%$ of students showed a preference as sensitive learners and $10 \%$ as intuitive learners. The majority of students (54\%) exhibited a strong preference for Visual learning instead of Verbal learning (6\%). Finally, on the Sequential-Global dimension, $64 \%$ and $8 \%$ of students showed preference as sequential and global learners respectively (see Table 3).

Table 3: Health science students' strengths of preferences at different ILS learning styles

\begin{tabular}{|c|c|c|c|c|c|c|c|c|c|c|c|}
\hline \multicolumn{3}{|c|}{ Active-Reflective \% } & \multicolumn{3}{|c|}{ Sensing-Intuitive \% } & \multicolumn{3}{|c|}{ Visual-Verbal \% } & \multicolumn{3}{|c|}{ Sequential-Global \% } \\
\hline Mod.str. & Mild & Mod.str. & Mod.str & Mild & Mod.str. & Mod.str & Mild & Mod.str. & Mod.str & Mild & Mod.str \\
\hline Active & & Reflect & Sensing & & Intuitive & Visual & & Verbal & Seqent & & Global \\
\hline 44.4 & 32.2 & 23.4 & 59.6 & 30.1 & 10.3 & 53.9 & 39.8 & 6.3 & 63.6 & 28.7 & 7.7 \\
\hline
\end{tabular}

\section{Student attitudes to e-learning}

The raw mean scores for the nine actual and preferred OLES scores are reported in Table 4. Figure 1 shows the mean item scores for health science students' actual and preferred OLES scores. Statistical testing (MANOVA for repeated measures) was completed to determine if any significant differences existed between the actual and preferred scores on the nine OLES subscales. The results indicated that there was a significant difference between the actual and preferred scores for all nine OLES subscales $(\mathrm{p}<.001$; see Figure 1).

Table 4: Descriptive statistics of the OLES actual and preferred subscales $(\mathrm{N}=822)$

\begin{tabular}{|c|c|c|c|}
\hline \multicolumn{2}{|c|}{ OLES subscale item } & Mean & SD \\
\hline \multirow{2}{*}{$\begin{array}{l}\text { Computer usage } \\
(\mathrm{CU})\end{array}$} & Actual & 3.3002 & .6371 \\
\hline & Preferred & 3.6760 & .7249 \\
\hline \multirow{2}{*}{$\begin{array}{l}\text { Teacher support } \\
\text { (TS) }\end{array}$} & Actual & 3.5546 & .6645 \\
\hline & Preferred & 4.6011 & .4200 \\
\hline \multirow{2}{*}{$\begin{array}{l}\text { Student interaction and } \\
\text { collaboration (SIC) }\end{array}$} & Actual & 3.8972 & .7220 \\
\hline & Preferred & 4.2084 & .6638 \\
\hline \multirow{2}{*}{$\begin{array}{l}\text { Personal relevance } \\
(\mathrm{PR})\end{array}$} & Actual & 3.7234 & .7147 \\
\hline & Preferred & 4.2864 & .5632 \\
\hline \multirow{2}{*}{$\begin{array}{l}\text { Authentic learning } \\
\text { (AL) }\end{array}$} & Actual & 3.7608 & .7471 \\
\hline & Preferred & 4.3477 & .5521 \\
\hline \multirow{2}{*}{$\begin{array}{l}\text { Student autonomy } \\
\text { (SA) }\end{array}$} & Actual & 4.2078 & .5958 \\
\hline & Preferred & 4.6533 & .4026 \\
\hline \multirow{2}{*}{$\begin{array}{l}\text { Equity } \\
\text { (EQ) }\end{array}$} & Actual & 4.2741 & .6428 \\
\hline & Preferred & 4.6686 & .4835 \\
\hline \multirow{2}{*}{$\begin{array}{l}\text { Enjoy } \\
(\mathrm{EN})\end{array}$} & Actual & 2.8427 & .9454 \\
\hline & Preferred & 3.2245 & 1.0383 \\
\hline \multirow{2}{*}{$\begin{array}{l}\text { Asynchronicity } \\
\text { (AS) }\end{array}$} & Actual & 3.5925 & .9524 \\
\hline & Preferred & 3.9617 & .9058 \\
\hline
\end{tabular}




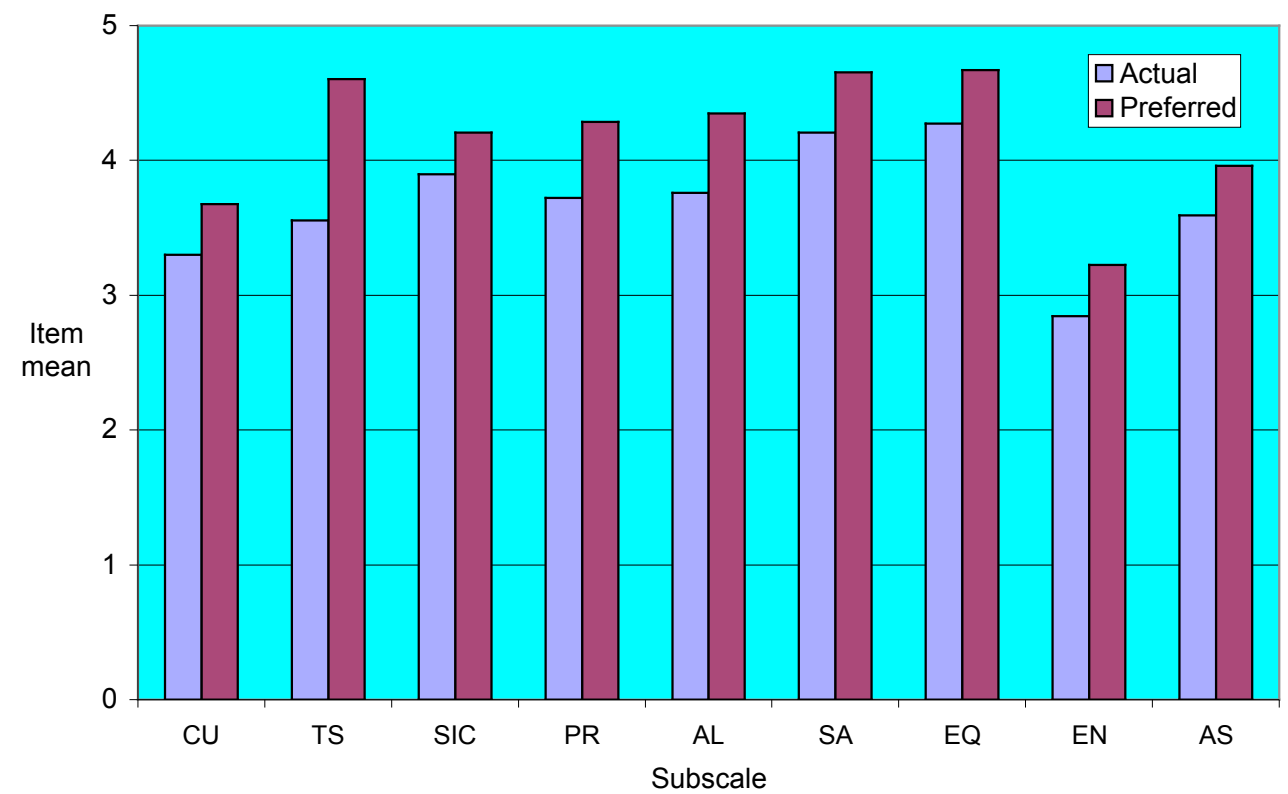

Figure 1: Average item mean for health science students' actual and preferred scores on the Online Learning Environment Survey. See Table 4 for key to OLES items. The MANOVA results indicated a significant difference between the actual and preferred scores for all nine subscales $\left({ }^{*} \mathrm{p}<.001\right)$.

\section{Regression analysis results}

Regression can be "used to explore the relationship between one continuous dependent variable and a number of independent variables or predictors" (Pallant, 2007 , p. 146). It is based on correlation, however allows for a more sophisticated examination of the interrelationship among a set of variables. Standard multi-linear regression was used to establish which, if any, of the four ILS learning style dimensions (independent variables) were found to significantly predict the scores of the nine OLES actual subscales (dependent variables). To meet the regression equation inclusion criterion, independent variables (four ILS learning style dimensions) had to significantly correlate with the dependent variables (nine OLES actual subscales).

The independent variables that met the significant correlation criterion $(\mathrm{p}<.05$ and $\mathrm{p}<.01$ ) for the nine OLES actual subscales dependent variables are listed in Table 5. Where there are empty cells on Table 5, this indicates that the independent variables were not significantly correlated with the dependent variables. The specific correlation coefficients are not reported. For example, the OLES actual Computer Usage dependent variable significantly correlated with three of the ILS independent variables whereas the OLES actual Teacher Support dependent variable only significantly correlated with one of the ILS independent variables. None of the four ILS learning style dimensions were significantly correlated with the OLES actual Student Autonomy or the Enjoyment dependent variables, hence regression analyses for these variables were not completed. 
The independent variables that met the significant correlation criterion $(\mathrm{p}<.05$ and $\mathrm{p}<.01)$ for the nine OLES preferred subscales dependent variables are listed in Table 6. Where there are empty cells on Table 6, this indicates that the independent variables were not significantly correlated with the dependent variables. The specific correlation coefficients are not reported. For example, the OLES preferred Computer Usage dependent variable significantly correlated with two of the ILS independent variables whereas the OLES preferred Teacher Support dependent variable significantly correlated with only one of the ILS independent variables. None of the four ILS learning style dimensions were significantly correlated with the OLES preferred Student Autonomy dependent variables, hence a regression analysis for this variable was not completed.

When the correlations between the independent variables were examined, none of the correlations exceeded 0.9. This indicated that multi-colinearity was unlikely to be an issue for the regression analyses involving the nine OLES actual and preferred subscale dependent variables. The normal probability plots and scatterplots for the nine OLES actual and preferred subscale dependent variables were visually examined. The nine sets of OLES actual and preferred subscale plots indicated that the distribution of residuals were acceptable and that the sample was linear, normally distributed, and homoscedastic.

Outliers were detected through inspection of the Mahalanobis distances. Using a $\mathrm{p}<.001$ criterion for Mahalanobis distance, 15 extreme multivariate outliers were identified. Pallant (2007) states that "it is not uncommon to find a number of outlying residuals" (p. 157) and if only a few outliers exist "it may not be necessary to take any action" (p. 157). Therefore, it was decided not to exclude the 15 outliers since the sample size was 822 participants. This indicates that the data is suitably correlated with the dependent variable for examination through multi-linear regression to be reliably undertaken.

Tables 5 and 6 report the regression models for OLES based on students' actual scores (Table 5) and preferred scores (Table 6). As it can be seen in both tables, variation in different subscales was affected by different learning styles. On Table 5, the ILS ActiveReflective, Sensing-Intuitive, and Visual-Verbal learning style dimensions accounted for $3.1 \%$ of the OLES actual Computer Usage scale variance. The ILS Sensing-Intuitive learning style accounted for $1.3 \%$ of the OLES actual Teacher Support scale variance. The ILS Active-Reflective, Sensing-Intuitive, and Visual-Verbal learning style dimensions accounted for $1.1 \%$ of the OLES actual Student Interaction and Collaboration scale variance. The ILS Active-Reflective and Sensing-Intuitive learning styles accounted for $6.2 \%$ of the OLES actual Personal Relevance scale variance.

The ILS Active-Reflective, and Sequential-Global learning styles accounted for $4.6 \%$ of the OLES actual Authentic Learning scale variance while the ILS Active-Reflective and Sensing-Intuitive learning style dimensions accounted for $2.3 \%$ of the variance of the OLES actual Equity scale variance. The ILS Sequential-Global learning style accounted for $1.7 \%$ of the OLES actual Asynchronicity subscale variance.

In Table 6, the ILS Active-Reflective and Visual-Verbal learning style dimensions accounted for $1.8 \%$ of the OLES preferred Computer Usage scale variance. The ILS Active-Reflective learning style scale accounted for $1.1 \%$ of the OLES preferred Teacher Support scale variance. The ILS Active-Reflective and Visual-Verbal learning style 
dimensions accounted for $6.7 \%$ of the OLES preferred Student Interaction and Collaboration scale variance. The ILS Active-Reflective, Sensing-Intuitive, and Sequential-Global learning styles accounted for $2.9 \%$ of the OLES preferred Personal Relevance scale variance.

Table 5: Regression models for the Online Learning Environment Survey (OLES) actual subscales

\begin{tabular}{|l|c|c|c|c|c|c|c|c|c|}
\hline \multirow{2}{*}{$\begin{array}{l}\text { Indepen. } \\
\text { variable }\end{array}$} & \multicolumn{8}{|c|}{ Dependent variables: Online Learning Environment Survey actual subscales } \\
& \multicolumn{1}{|c|}{ CU } & TS & SIC & PR & AL & SA & EQ & EN & AS \\
\hline ACT.REF & 0.089 & & 0.305 & 0.181 & 0.171 & & 0.104 & & \\
& $(0.019)$ & & $(0.000)$ & $(0.000)$ & $(0.000)$ & & $(0.003)$ & & \\
\hline SNS.INT & 0.092 & -0.088 & 0.064 & 0.041 & & & -0.113 & & \\
& $(0.012)$ & $(0.016)$ & $(0.055)$ & $(0.278)$ & & & $(0.001)$ & & \\
\hline VIS.VRB & 0.089 & & 0.039 & & & & & & 0.117 \\
& $(0.021)$ & & $(0.262)$ & & & & & & $(0.001)$ \\
\hline SEQ.GLO & & & & & -0.041 & & & & \\
& & & & & $(0.258)$ & & & & \\
\hline $\mathrm{R}^{2}$ & 0.031 & 0.013 & 0.113 & 0.062 & 0.046 & & 0.023 & & 0.017 \\
\hline F-ratio & 7.633 & 4.962 & 26.065 & 10.746 & 9.843 & & 9.607 & & 6.531 \\
\hline P-value & 0.000 & 0.007 & 0.000 & 0.000 & 0.000 & & 0.000 & & 0.002 \\
\hline
\end{tabular}

CU: Computer usage; TS: Teacher support; SIC: Student interaction and collaboration; PR: personal relevance; AL: Authentic learning; SA: Student autonomy; EQ: Equity; EN: Enjoyment; AS: Asynchronicity; ACT-REF: Active-Reflective; SENS-INT: Sensing-Intuitive; VIS-VRB: VisualVerbal; SEQ-GLO: Sequential-Global.

Note: Where there are empty cells on Table 5, this indicates that the independent variables were not significantly correlated with the dependent variables.

Table 6: Regression models for Online Learning Environment Survey (OLES) preferred subscales

\begin{tabular}{|c|c|c|c|c|c|c|c|c|c|}
\hline \multirow{2}{*}{$\begin{array}{l}\text { Indepen. } \\
\text { variable }\end{array}$} & \multicolumn{9}{|c|}{$\begin{array}{c}\text { Dependent variables: Online Learning Environment Survey preferred subscales } \\
\text { Standardised beta (P-value) }\end{array}$} \\
\hline & $\mathrm{CU}$ & TS & SIC & PR & AL & SA & EQ & EN & AS \\
\hline ACT.REF & $\begin{array}{c}0.061 \\
(0.090)\end{array}$ & $\begin{array}{c}0.104 \\
(0.003)\end{array}$ & $\begin{array}{l}0.187 \\
(0.000)\end{array}$ & $\begin{array}{l}0.097 \\
(0.005)\end{array}$ & $\begin{array}{c}0.143 \\
(0.000)\end{array}$ & & $\begin{array}{c}0.161 \\
(0.000)\end{array}$ & & \\
\hline SNS.INT & & & & $\begin{array}{l}-0.042 \\
(0.256)\end{array}$ & $\begin{array}{l}-0.034 \\
(0.376)\end{array}$ & & $\begin{array}{l}0.090 \\
(0.009)\end{array}$ & & \\
\hline VIS.VRB & $\begin{array}{c}0.103 \\
(0.004)\end{array}$ & & $\begin{array}{c}0.094 \\
(0.008)\end{array}$ & & & & & & \\
\hline SEQ.GLO & & & & $\begin{array}{l}-0.066 \\
(0.077)\end{array}$ & $\begin{array}{l}-0.072 \\
(0.054)\end{array}$ & & & $\begin{array}{c}-0.074 \\
(0.034)\end{array}$ & $\begin{array}{l}0.116 \\
(0.001)\end{array}$ \\
\hline $\mathrm{R}^{2}$ & 0.018 & 0.011 & 0.067 & 0.029 & 0.037 & & 0.033 & 0.005 & 0.013 \\
\hline F-ratio & 7.429 & 9.034 & 19.704 & 4.944 & 7.865 & & 13.972 & 4.528 & 11.137 \\
\hline P-value & 0.001 & 0.003 & 0.000 & 0.000 & 0.000 & & 0.000 & 0.034 & 0.001 \\
\hline
\end{tabular}

CU: Computer usage; TS: Teacher support; SIC: Student interaction and collaboration; PR: personal relevance; AL: Authentic learning; SA: Student autonomy; EQ: Equity; EN: Enjoyment; AS: Asynchronicity; ACT-REF: Active-Reflective; SENS-INT: Sensing-Intuitive; VIS-VRB: VisualVerbal; SEQ-GLO: sequential-global.

Note: Where there are empty cells on Table 6, this indicates that the independent variables were not significantly correlated with the dependent variables.

The ILS Active-Reflective, Sensing-Intuitive, and Sequential-Global learning styles accounted for $3.7 \%$ of the OLES preferred Authentic Learning scale variance while the ILS Active-Reflective and Sensing-Intuitive accounted for 3.3\% of the OLES preferred 
Equity scale variance. The ILS Sequential-Global learning style accounted for $0.5 \%$ and $1.7 \%$ of the OLES preferred Enjoyment and Asynchronicity subscale variances respectively.

In summary, only small percentages of variance, ranging from $1.1 \%$ to $11.3 \%$, were found for seven out of the nine OLES actual subscales and eight out of the nine OLES preferred subscales. For the OLES actual subscales, the ILS Active-Reflective and Sensing-Intuitive learning style dimensions were the most frequent predictors while the Sequential-Global learning style was a significant predictor only for one OLES subscale. For the OLES preferred subscales, ILS Active-Reflective and Sequential-Global learning style dimensions accounted for the most frequent source of variance, while the ILS Visual-Verbal learning style dimension was the least frequent source of OLES preferred subscale variance. In other words, the learning style scales of the ILS can be used as a predictor of health science student attitudes towards e-learning.

\section{Discussion}

"Questioning how a particular type of technology influences the learning styles of students and using that information in designing a course provide a theoretical justification for the method. And there is no question that learning styles should be taken into account when teaching with technology" (Grasha \& Yangarber-Hicks, 2000, p. 3). In the present study, the learning style preferences, attitudes towards e-learning, and the relationship between them amongst a group of health science students were examined. The results indicated that almost 30\% of the health science students did not report a strong preference in their learning style. On the ILS Active-Reflective dimension, $44.4 \%$ of health science students showed a preference as active learners, $60 \%$ as sensitive learners, and $64 \%$ as sequential learners.

Assessment of health science students' attitudes toward e-learning using OLES showed that their preferred scores for all nine subscales were higher than their actual scores. The linear regression analysis findings demonstrated that the ILS learning style dimensions can be used as predictors of health science student attitudes towards elearning as defined by the OLES. For the OLES actual subscales, the ILS ActiveReflective and Sensing-Intuitive learning style dimensions were the most frequent predictors of health science students' attitudes towards e-learning. For the OLES preferred subscales, ILS Active-Reflective and Sequential-Global learning style dimensions accounted for the most frequent source of variance of health science students' attitudes towards e-learning.

Studies have suggested that students interested in technology based instruction (elearning) are independent learners who prefer a more abstract way of thinking (Grasha \& Yangarber-Hicks, 2000). For example, Diaz and Cartnal (1999) compared two groups of students taking the same course: students in a traditional lecture stream and students taking an online version. Those students in the technology section were more independent and less dependent on their styles as learners. "The implication of the work on learning styles and technology is that students who prefer, and benefit from, learning in technologically based courses are different from those who prefer more traditional courses" (Grasha \& Yangarber-Hicks, 2000, p. 4). Therefore, the ILS learning style dimensions of active/reflective, sensing/intuitive, visual/verbal, and sequential/global need to be taken into consideration in relation to their impact on student learning in e-learning and distance education contexts. 
McNulty, Espiritu, Halsey and Mendez (2006) found similar results to this study. They tested the hypothesis that personality preference, which is related to learning style, influenced individual utilisation of computer assisted instruction applications developed specifically for undergraduate medical students. They found that students with a "Sensing" preference tended to use computer assisted instruction applications more frequently than the "Intuitives". They concluded that personality/learning preferences of individual medical students influence their use of computer assisted instructions (McNulty et al., 2006). In another study, Federico (2000) reported that students with assimilating and accommodating learning styles exhibited more favourable attitudes towards network based instruction than students with converging and diverging learning styles. This would be comparable to the OLES actual and preferred Computer Usage, Student Interaction and Collaboration, and Personal Relevance subscales being predicted by the ILS learning style dimensions.

In another study, Engleberg, et al. (2001) examined the learning styles and perceptions of the value of various learning modalities before and after a second year course in microbiology and infectious diseases. Their course consisted of lectures, small group sessions, interactive computer assisted learning, and textbook readings. They assessed how individual learning styles influenced learners' value assessment of these teaching modalities and found that at the beginning of the course, learners with a relative preference for experiential learning, rather than abstraction, initially favoured small groups and computer-assisted learning. Similarly, learners with a preference for reflective observation rather than active experimentation favoured lectures. However, at the end of the course, learning style did not predict the value assessment of any teaching modality. Yoder (1984) found that reflective learners did better with traditional lecture style learning contexts while active learners did better with interactive computer assisted learning.

The results of the study are in contrast with the results of Steele and colleagues (2002) where they found no relationship between learning preferences and attitudes towards computers amongst a group of 151 medical students. Lynch, Steele, Palensky, Lacy and Duffy (2001) examined whether learning preferences and attitudes towards computers influenced the acquisition of knowledge via computer assisted instruction amongst a group of 180 students. Their results indicated that there was no correlation between students' learning preferences or attitudes towards computers and CAI knowledge acquisition.

Hoisington (2000) explored whether there was a relationship between learning styles and nursing students' comfort in using the Internet/world wide web. No statistically significant relationship was found between students' results and perceived Internet comfort and their learning styles. Similar to Hoisington, McLaughlin (2001) found no correlations between the learning styles of graduate nurses taking web based courses and their perceived satisfaction with the course delivery mode. In a group of 33 dental hygiene students, Fleming, Mauriello, McKaig and Ludlow (2003) found no significant difference between learning styles in students participating in web based learning tasks versus conventional lectures with slides. In a study of 18 physical therapy assistant students, Thompson (1987) found no significant correlation between student learning styles and attitudes towards computer assisted learning. This is similar to the results obtained in this study where none of the ILS learning style dimensions were predictive of the OLES actual and preferred Student Autonomy subscales and the actual Enjoyment subscale. 


\section{Study limitations}

There are several inherent limitations with this study. Convenience sampling was used to recruit participants therefore respondent bias may be an issue. Only students enrolled in health science programs from one university were included in the sample and this limits the generalisability of the results. Only a limited number of independent variables from one valid and reliable scale were included in the regression analysis, hence other significant predictors may not have been accounted for. However, a balance between reasonable respondent burden and eliciting students' opinions had to be achieved.

\section{Recommendations for future research}

There are several recommendations for future research related to this study. Firstly, a similar study could be completed with health science students from a broader sampling base. For example, students enrolled in other health care professions such as audiology, optometry, medicine, chiropractic, orthoptics, podiatry, and prosthetics and orthotics could be included in a larger sample. As well, students from multiple universities could be included to ensure adequate geographical representation. Secondly, a similar study could be completed comparing health science students with other student cohorts such as law, engineering, information technology, business, or education. Thirdly, other questionnaires examining other constructs could be included to try and establish other significant predictors to e-learning. Finally, student participants could be randomly selected to take part in the study to minimise the issue of respondent bias.

\section{Conclusion}

The relationship between learning styles and attitudes to e-learning has received limited attention in the empirical literature to date. Using the a self report survey consisting of the Index of Learning Styles (ILS) and the Online Learning Environment Survey (OLES), this study investigated whether the learning style preferences of a group of health science students were predictive of their attitudes to e-learning. The survey was distributed to 2885 students enrolled in ten different health science programs at an Australian university. A total of 822 useable surveys were returned generating a response rate of $29.3 \%$. A linear regression analysis was completed.

On the ILS Active-Reflective dimension, $44.4 \%$ of health science students showed a preference as active learners, $60 \%$ as sensitive learners, and $64 \%$ as sequential learners. Students' attitudes toward e-learning using OLES showed that their preferred scores for all nine subscales were higher than their actual scores. The linear regression analysis results indicated that only small percentages of variance, ranging from $1.1 \%$ to $11.3 \%$, were found for seven out of the nine OLES actual subscales and eight out of the nine OLES preferred subscales. For the OLES actual subscales, the ILS Active-Reflective and Sensing-Intuitive learning style dimensions were the most frequent predictors of attitudes to e-learning while the Sequential-Global learning style was only a significant predictor for one OLES subscale. For the OLES preferred subscales, ILS ActiveReflective and Sequential-Global learning style dimensions accounted for the most frequent predictors of attitudes to e-learning while the ILS Visual-Verbal learning style dimension was the least frequent source of OLES preferred subscale variance. 
In summary, it appears that the learning styles (as measured by the ILS) of health science students can be used to a limited extent as a predictor of students' attitudes towards e-learning (as measured by the OLES). Educators of health science students should therefore consider the learning styles of the students they teach, especially when using technology or aspects of e-learning.

\section{Acknowledgments}

The students who volunteered their time and input to complete the survey are thanked. Acknowledgments are extended to the Monash University Faculty of Medicine, Nursing and Health Sciences Learning and Teaching Performance Fund Project Grants Scheme that provided the funding for the completion of this project.

\section{References}

Aldridge, J., Dorman, J. \& Fraser, B. J. (2004). Use of multitrait-multimethod modelling to validate actual and preferred forms of the Technology-Rich Outcomes-Focused Learning Environment Inventory (TROFLEI). Australian Journal of Educational E Developmental Psychology, 4, 110-125.

Aldridge, J., Fraser, B., et al. (2003). Monitoring the success of an outcomes-based, technologyrich learning environment. Paper Presented at the Annual Meeting of the American Educational Research Association, Chicago, IL.

Alonso, F., Lopez, G., Manrique, D. \& Vines, J. M. (2005). An instructional model for web-based e-learning education with a blended learning process approach. British Journal of Educational Technology, 36(2), 217-235.

Arthurs, J. B. (2007). A juggling act in the classroom: Managing different learning styles. Teaching and Learning in Nursing, 2, 2-7.

Brudenell, I. \& Carpenter, C. S. (1990). Adult learning styles and attitudes toward computer assisted instruction. Journal of Nursing Education, 29, 79-83.

Chang, B. L. (1984). Adoption of innovations: Nursing and computer use. Computers in Nursing, 2(6), 229-235.

Clayton, J. (2007). Validation of the online learning environment survey. In ICT: Providing choices for learners and learning. Proceedings Ascilite Singapore 2007.

http: / / www.ascilite.org.au/conferences/ singapore07/procs/clayton.pdf

Coffield, F., Moseley. D., Hall, E. \& Eccleston, K. (2004). Learning styles and pedagogy in post-16 learning: A systematic and critical review. London, UK: Learning and Skills Research Centre. [verifed 16 Aug 2009] https: / / crm.lsnlearning.org.uk/ user/ order.aspx?code=041543

Cook, D. A. (2005). Learning and cognitive styles in web-based learning: Theory, evidence and application. Academic Medicine, 80, 266-278.

Diaz, D. \& Cartnal, R. B. (1999). Student learning styles in an online course and an equivalent oncampus class. College Teaching, 47(4), 130-135.

Dunn, R. \& Griggs, S. (2003). Synthesis of the Dunn and Dunn learning styles model research: Who, what, when, where and so what - the Dunn and Dunn learning styles model and its theoretical cornerstone. New York: St John's University. 
Effken, J. A. \& Doyle, M. (2001). Interface design and cognitive style in learning an instructional computer simulation. Computers in Nursing, 19, 164-171.

Engleberg, N. C., Schwenk, T. \& Gruppen, L. D. (2001). Learning styles and perceptions of the value of various learning modalities before and after a 2 nd-year course in microbiology and infectious disease. Teaching and Learning in Medicine, 13, 253-257.

Felder, R. M. \& Silverman, L. K. (1988). Learning and teaching styles in engineering education. Engineering Education, 78(7), 674-681.

Felder, R. M. (1993). Reaching the second tier: Learning and teaching styles in college science education. Journal of College Science Teaching, 23(5), 286-290.

Felder, R. M. \& Spurlin, J. (2005). Applications, reliability and validity of the Index of Learning Styles. International Journal of Engineering Education, 21(1), 103-112.

Fleming, D. E., Mauriello, S. M., McKaig, R. G. \& Ludlow, J. B. (2003). A comparison of slide/audiotape and web-based instructional formats for teaching normal intraoral radiographic anatomy. The Journal of Dental Hygiene, 77, 27-35.

Fraser, B. J. (1981). TOSRA Test of Science-Related Attitudes handbook. Hawthorn, VIC: Australian Council for Educational Research.

Fraser, B. J. (1998a). Classroom environment instruments: Development, validity and applications. Learning Environments Research: An International Journal, 1(1), 68-93.

Fraser, B. J. (1998b). Science learning environments: Assessment, effects and determinants. In B. Fraser \& K. G. Tobin (Eds.), International handbook of science education (pp. 527-564). Dordrecht: Kluwer Academic Publishers.

Federico, P-A. (2000). Learning styles and student attitudes toward various aspects of networkbased instruction. Computers in Human Behavior, 16(4), 359-379.

Graff, M. (2003). Cognitive style and attitudes towards using online learning and assessment methods. Electronic Journal of e-Learning, 1(1), 21-28. [verified 16 Aug 2009] http:/ / www.ejel.org/volume-1-issue-1/issue1-art3-graff.pdf

Grasha, A. F. \& Yangarber-Hicks, N. (2000). Integrating teaching styles and learning styles with instructional technology. College Teaching, 48, 2-10.

Hickcox, L. (1995). Learning styles: A survey of adult learning style inventory models. In R. Sims \& S. Sims (Eds.), The importance of learning styles: Understanding the implications for learning, course design, and education (pp. 25-46). Westport, CT: Greenwood.

Hoisington, D. L. (2000). Use of technology by nursing students: Learning styles, age, and experience. Michigan State University: Unpublished doctoral thesis.

Hong, H. \& Kinshuk (2004). Adaptation to student learning styles in web based educational systems. In L. Cantoni \& C. McLoughlin (Eds.), Proceedings of ED-MEDIA 2004 - World Conference on Educational Multimedia, Hypermedia \& Telecommunications, (p.491-496), Lugano, Switzerland, USA: AACE.

Huston, J. L. \& Cohen, T. L. (1995). How learning style and personality type can affect performance. Health Care Supervision, 13, 38-45. 
Jegede, O., Fraser, B. \& Fisher, D. L. (1995). The development and validation of a distance and open learning environment scale. Educational Technology Research \& Development, 43, 90-93.

Kirchhoff, K. T. \& Holzemer, W. L. (1979). Student learning and a computer-assisted instructional program. Journal of Nursing Education, 18, 22-30.

Kolb, D. A. (1984). Experiential learning: experience as the source of learning and development. Englewood Cliffs, NJ: Prentice Hall.

Liegle, J. O. \& Janicki, T. N. (2006). The effect of learning styles on the navigation needs of Webbased learners. Computers in Human Behavior, 22, 885-898.

Liberman, G., Abramson, R., Squires, F. B., Glassman, J. R., Morris, E. A. \& Dershaw, D. D. (2002). Tutor versus computer: A prospective comparison of interactive tutorial and computer-assisted instruction in radiology education. Academic Radiology, 9, 40-49.

Litzinger, T. A., Lee, S. H., Wise, J. C., \& Felder, R. M. (2007). A psychometric study of the Index of Learning Styles. Journal of Engineering Education, 96(4), 309-319.

Loo, R. (2004). Kolb's learning styles and learning preferences: is there a linkage? Educational Psychology, 24, 99-108.

Lu, J., Yu, C-S., \& Liu, C. (2003). Learning style, learning patterns, and learning performance in WebCT-based MIS course. Information E Management, 40, 497-507.

Lynch, T. G., Steele, D. J., Johnson Palensky, J. E., Lacy, N. L. \& Duffy, S. W. (2001). Learning preferences, computer attitudes, and test performance with computer-aided instruction. American Journal of Surgery, 181, 368-371.

Lynch, T. G., Woelfl, N. N., Steele, D. J. \& Hanssen, C. S. (1998). Learning style influences student examination performance. American Journal of Surgery, 176, 62-66.

Mayer, R. E. (2003). Elements of a science of e-learning. Journal of Educational Computing Research, 29(3), 297-313.

McLaughlin, D. G. (2001). Research on learning styles of students who are taking Web-based courses. Idaho State University: Unpublished doctoral thesis.

McNulty, J. A., Espiritu, B., Halsey, M. \& Mendez, M. (2006). Personality preference influences medical student use of specific computer-aided instruction (CAI). BMC Medical Education 2006, 6(7). http: / / www.biomedcentral.com/1472-6920/6/7

Ogilvie, R. W., Trusk, T. C. \& Blue, A. V. (1999). Students' attitudes towards computer testing in a basic science course. Medical Education, 33, 828-831.

Pallant, J. F. (2007). SPSS survival manual: A step-by-step guide to data analysis with SPSS (3rd ed.). Crows Nest, NSW: Allen \& Unwin.

Romanov, K. \& Nevgi, A. (2007). Do medical students watch video clips in eLearning and do these facilitate learning? Medical Teacher, 29(5), 490-494.

Shaw, G. \& Marlow, N. (1999). The role of student learning styles, gender, attitudes and perceptions on information and communication technology assisted learning. Computers $\mathcal{E}$ Education, 33, 223-234. 
Shih, J. A. \& Gamon, C. C. (2002). Relationships among learning strategies, patterns, styles, and achievement in web-based courses. Journal of Agricultural Education, 43(4), 1-11.

Sims, R. J. \& Sims, S. J. (2006). Learning styles and learning: A key to meeting the accountability demands in education. New York: Nova Science Publishers.

Startsman, T. S. \& Robinson, R. E. (1972). The attitudes of medical and paramedical personnel toward computers. Computers in Biomedical Research, 5, 218-227.

Stein, F. \& Cutler, S.K. (2000). Clinical research in occupational therapy. San Diego, CA: Singular Publishing Group, Thomson Learning.

Steele, D. F., Palensky, J. E. J., Lynch, T. G., Lacy, N. L. \& Duffy, S. W. (2002). Learning preferences, computer attitudes, and student evaluation of computerised instruction. Medical Education, 36, 225-232.

Summers, S., Carty, S. et al. (1993). Educational implications of nurses' brain dominance, learning styles, and attitudes toward computerization. Journal of Nursing Staff Development, 9, 35-39.

Tabachnick, B. G. \& Fidell, L. S. (2007). Using multivariate statistics, 5th ed. Boston, MA: Allyn and Bacon.

Taylor, P. C., Fraser, B. J. \& Fisher, D. L. (1997). Monitoring constructivist classroom learning environments. International Journal of Educational Research, 27, 293-302.

Thompson, E. C. (1987). Computer-assisted instruction in curricula of physical therapy assistants. Physical Therapy, 67, 1237-1239.

The University of Northampton (2008). Definition of e-Learning. [viewed 17 March 2009] http:/ / www2.northampton.ac.uk/ portal/page/ portal/learningandteaching/students/elearning/e-learningdefinition

Titiloye, V. M. \& Scott, A. H. (2001). Occupational therapy students' learning styles and application to professional academic training. Occupational Therapy in Health Care, 15(1/2), $145-155$.

Trinidad, S., Aldridge, J. \& Fraser, B. (2005). Development, validation and use of the Online Learning Environment Survey. Australian Journal of Educational Technology, 21(1), 60-81. http: / / www.ascilite.org.au/ajet/ajet21/trinidad.html

Van Dover, L. \& Boblin, S. (1991). Student nurse computer experience and preferences for learning. Computers in Nursing, 9, 75-79.

Walker, S. \& Fraser, B. (2005). Development and validation of an instrument assessing distance education learning environments in higher education: The Distance Learning Environment Survey (DELES). Learning Environments Research: An International Journal, 8(3), 289-308.

Yoder, M. E. (1994). Preferred learning style and educational technology: Linear vs. interactive video. Nursing $\mathcal{E}$ Health Care, 15, 128-132.

Zywno, M. S. (2003). A contribution to validation of score meaning for Felder-Soloman's Index of Learning Styles. Proceedings of the 2003 ASEE Annual Conference. Nashville, TN. [viewed 18 Nov 2008, verified 16 Aug 2009]. http: / / www.ncsu.edu/ felderpublic/ILSdir/Zywno_Validation_Study.pdf 
Dr Ted Brown, PhD, OT(C), OTR, AccOT, Senior Lecturer, Department of Occupational Therapy, School of Primary Health Care, Faculty of Medicine, Nursing and Health Sciences, Monash University - Peninsula Campus, Frankston, Victoria, Australia. Email: ted.brown@med.monash.edu.au

Dr Maryam Zoghi, PT, PhD, School of Physiotherapy, Faculty of Medicine, Dentistry, and Health Sciences, University of Melbourne, Carleton, Victoria, Australia

Mr Brett Williams, PhD (Candidate), MHlthSc, MACAP, Senior Lecturer, Department of Community Emergency Health and Paramedic Practice, School of Primary Health Care, Faculty of Medicine, Nursing and Health Sciences, Monash University Peninsula Campus, Frankston, Victoria, Australia

Dr Shapour Jaberzadeh, PhD, Senior Lecturer, Department of Physiotherapy, School of Primary Health Care, Faculty of Medicine, Nursing and Health Sciences, Monash University - Peninsula Campus, Frankston, Victoria, Australia

Dr Louis Roller, $P h D$, Associate Professor, Faculty of Pharmacy and Pharmaceutical Sciences, Victorian College of Pharmacy, Monash University - Parkville Campus, Parkville, Victoria, Australia

Ms Claire Palermo, Lecturer, Nutrition and Dietetics Unit, Department of Medicine, Faculty of Medicine, Nursing and Health Sciences, Monash Medical Centre, Clayton, Victoria, Australia

Dr Lisa McKenna, PhD, Associate Professor, School of Nursing and Midwifery, Faculty of Medicine, Nursing and Health Sciences, Monash University - Peninsula Campus, Frankston, Victoria, Australia

Ms Caroline Wright, Lecturer (Radiation Sciences), Department of Medical Imaging \& Radiation Sciences, School of Biomedical Sciences, Faculty of Medicine, Nursing and Health Sciences, Monash University - Clayton Campus, Clayton, Victoria, Australia

Dr Marilyn Baird, PhD, Associate Professor \& Head, Department of Medical Imaging \& Radiation Sciences, School of Biomedical Sciences, Faculty of Medicine, Nursing and Health Sciences, Monash University - Clayton Campus, Clayton, Victoria, Australia

Dr Michal Schneider-Kolsky, PhD, Senior Lecturer, Department of Medical Imaging \& Radiation Sciences, School of Biomedical Sciences, Faculty of Medicine, Nursing and Health Sciences, Monash University - Clayton Campus, Clayton, Victoria, Australia

Ms Lesley Hewitt, Lecturer, Department of Social Work, School of Primary Health Care, Faculty of Medicine, Nursing and Health Sciences, Monash University Caulfield Campus, Caulfield, Victoria, Australia

Dr Jenny Sim, PhD, Senior Lecturer, Medical Radiations, School of Medical Sciences, Bundoora West Campus, RMIT University, Bundoora, Victoria, Australia

Dr Tangerine-Ann Holt, $P h D$, Senior Lecturer, Centre for Medical and Health Sciences Education, Faculty of Medicine, Nursing and Health Sciences, Monash University, Notting Hill, Victoria, Australia 